\title{
https://doi.org/10.46813/2020-130-127 \\ PLASMA-CHEMICAL METHOD OF GRAIN FUNGAL CONTAMINATION CONTROL
}

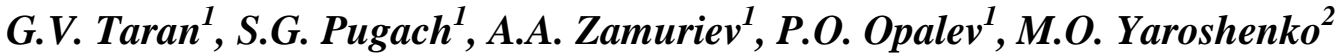 \\ ${ }^{1}$ National Science Center "Kharkov Institute of Physics and Technology", Kharkiv, Ukraine; \\ ${ }^{2}$ National Scientific Center "Institute of Experimental and Clinical Veterinary Medicine" \\ (NSC “IECVM"), Kharkiv, Ukraine \\ E-mail: tarang@kipt.kharkov.ua
}

The experimental results on the effect of grain treatment with ozone-air mixture on the level of artificial grain contamination with micromycetes are presented. The contamination dynamics for $1000 \mathrm{~kg}$ of wheat grain contaminated with Penicillium nordicum and Aspergillus flavus and stored in the prototype grain storage unit in ozone environment for 6 months is shown. The study on the effect of ozone on the growth inhibition of Aspergillus flavus for maize grain and Penicillium verrucosum for wheat grain in a $100 \mathrm{dm}^{3}$ silo is presented. The effect of ozone on the content of aflatoxins in maize grain additionally contaminated with Aspergillus flavus is studied. The efficiency of ozone technologies for large-scale grain storage, as well as for reducing fungal contamination and controlling mycotoxin content in food grains, is shown.

PACS: 52.75.-d, 52.77.-j, 52.90.+z, 81.20.-n

\section{INTRODUCTION}

The most attractive aspects of its application in comparison with the traditional chemical and technological processes are no liquid solutions required and significantly lower energy consumption in these plasma processes. Plasma processes are potentially environmentally-friendly.

Also, plasma processes are more energy efficient. Physical and chemical activities of plasma have been known for more than 100 years. However, the systematic extensive studies on chemical reactions under such conditions began only in the late 50s after significant advances in plasma physics were achieved and highvoltage equipment was developed [1].

The main feature of plasma-chemical processes is that many reactive particles, such as excited molecules, electrons, atoms, atomic and molecular ions, free radicals (some of these particles can be formed only in plasma) responsible for the new types of chemical reactions, are formed in plasma in much higher concentrations than under normal conditions of chemical reactions. Plasmachemical reactions, as a rule, are multichannel processes, due to which the whole variety of experimental reactions is determined in low-temperature plasma. [2, 3]. By changing the conditions of plasma generation and regulation of its composition, reactions can be directed through one or another channel [4].

The main feature of plasma-chemical processes is formation of reactive particles in plasma in much higher concentrations, than under normal conditions of chemical reactions. The reactive articles such as excited molecules, electrons, atoms, atomic and molecular ions, free radicals (some of these particles can be formed only in plasma) are responsible for new types of chemical reactions. Plasma-chemical reactions, as a rule, are multichannel processes, due to which the whole variety of experimental reactions is determined in low-temperature plasma. [2, 3]. By changing the conditions of plasma generation and regulation of its composition, reactions can be directed through one or another channel [4].
One of the most promising types of gas discharge for effective implementation of plasma-chemical processes is a barrierless discharge which occurs in sharply inhomogeneous electric fields and is characterized by a diffuse glow in the discharge gap. This type of discharge is characterized by ionization propagation over the entire discharge gap, which makes it possible to obtain large amounts of weakly ionized gas at atmospheric pressure [5].

The issue of environmental pollution and contamination of feed substrates with the spores of microscopic fungi becomes more acute every year [6-9]. This problem is associated with violation of ecological balance in myco- and microcenoses, increasing the photooxidant concentration in the atmosphere (air pollution), decreasing the resistance to phytopathogens and using fertilizers and pesticides

Each type of parasitic fungi has its own physiological characteristics and methods of influence on the growth substrate, respectively. The development of such fungi as Aspergillus flavus in maize grain and Penicillium verrucosum in wheat grain during storage leads to product quality deterioration. As a result, such grain cannot be used for food purposes [7]. Therefore, the main goal of the experimental studies was to determine the ozone treatment effect on the level of contamination with micromycetes at artificial contamination. A wheat grain was artificially contaminated with Penicillium verrucosum and a maize grain - with Aspergillus flavus. The effect of ozone on the content of aflatoxins in maize grain additionally contaminated with Aspergillus flavus was studied.

\section{MATERIAL AND METHOD}

The effect of ozone on fungal infection was studied using the prototype unit for wheat storage in ozone environment. The prototype consists of the following functional units: the air compressor GOORUI (China) with a capacity of up to $47 \mathrm{~m}^{3} / \mathrm{h}$ and the maximum pressure of up to $100 \mathrm{kPa}$, the float-type flowmeter (DFG-25), the ozone generator "Stream Ozone" with the maximum ozone productivity of $10 \mathrm{~g} / \mathrm{h}$, the ozone meter 
"Stream Ozone" with a measurement range of $0 \ldots 1000 \mathrm{ppm}$, the silo prototype with a volume of $2 \mathrm{~m}^{3}$ made of moisture-resistant wooden board OSB-3 to accommodate $1 \mathrm{t}$ of grain (Fig. 1). Some part of grain $(250 \mathrm{~kg}$ ) was artificially contaminated with a complex of fungi (Aspergillus flavus and Penicillium nordicum) to study.

Ozone-air mixture with the flow rate of $17 \mathrm{~m}^{3} / \mathrm{h}$ was fed to the grain. Ozone concentration in the mixture was $100 \mathrm{mg} / \mathrm{m}^{3}$ ( $\left.\sim 50 \mathrm{ppm}\right)$. The treatment was carried out every other week within 3 days. Sampling was carried out once a month. Both the quantitative (the number of spores in $1 \mathrm{~g}$ of grain) and qualitative characteristics of contamination (the percentage of contaminated grain in its total mass) were studied. During the experiment, the ambient temperature was monitored.

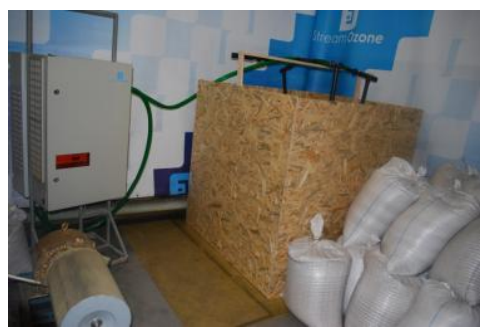

Fig. 1. The silo simulator for a ton of grain

To study the effect of ozone on the inhibition of Aspergillus flavus and Penicillium verrucosum growth in artificially contaminated maize and wheat (grain weight of $100 \mathrm{~kg}$, respectively), a model silo with the volume of $100 \mathrm{dm}^{3}$ was developed (Fig. 2). The grain was treated for 3 days once in 2 weeks in a 100-liter silo simulator. Ozone concentration in the mixture was $100 \mathrm{mg} / \mathrm{m}^{3}$. The grain was stored at the temperature of $15 \ldots 20{ }^{\circ} \mathrm{C}$ and humidity of $40 \ldots 50 \%$.

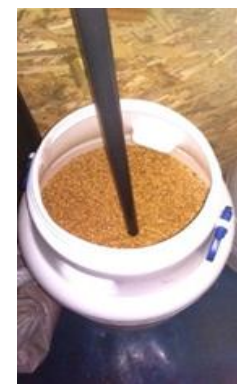

Fig. 2. The silo simulator for $100 \mathrm{~kg}$ of grain

The content of mycotoxins in wheat and maize samples was studied using a specially designed experimental stand. The experimental stand included such functional units as the air compressor "Secoh sangyo" (Japan) with the capacity up to $50 \mathrm{l} / \mathrm{min}$ and the maximum pressure up to $12.7 \mathrm{kPa}$, gas flow meter (RM4 GU3), laboratory ozone generator "Ozone-agro 1L", ozone monitor "Teledyne instruments" (USA) $454 \mathrm{H}$ with the measuring range of $0.1 \ldots 100 \mathrm{~g} / \mathrm{m}^{3}$, test chamber for samples and ozone destructor (Fig. 3).

Liquid chromatography method (LC/MS/MS) was used to study the content of Aflatoxins (B1, B2, G1, G2) in the wheat grain volume additionally contaminated with Penicillium verrucosum at a low level of fungal contamination (less than $1 \cdot 10^{4}$ spores $/ g$ ). The samples of wheat and maize grain were treated with ozone-air mixture for 3 days. The ozone concentration was $100 \mathrm{mg} / \mathrm{m}^{3}$.

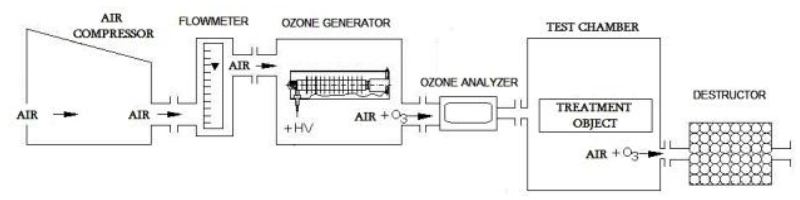

Fig. 3. The block diagram of the third experimental stand

To obtain a high level of fungal contamination (about $3 \cdot 10^{5}$ spores $/ g$ ), the culture of Aspergillus flavus was incubated on a sterile maize grain at the humidity of $70 \%$ and temperature of $27{ }^{\circ} \mathrm{C}$ for 14 days in thermostat. Then the whole mass of the contaminated maize was divided into two parts in the ratio of 1 to 3. One part was kept as a reference and 3 parts were treated with ozone at the output concentration of $100 \mathrm{mg} / \mathrm{m}^{3}$. The samples of treated maize were taken after 3, 4, and 5 days of treatment.

Mycotoxin content was determined in accordance with the "Guidelines for sanitary-mycological assessment and improvement of feed quality" by thin-layer chromatography (TLC) on "Sorbfil" plates. The plates were chromatographed in TEM (toluene-ethyl acetateformic acid) system at the ratio of 6:3:1. To detect Aflatoxin B, the plates were examined under a UV radiation source with the wavelength of 254 and $365 \mathrm{~nm}$ (chromatographic emitter UFS-254). Aflatoxin B was visualized as a fluorescent bright blue spot of $\mathrm{Rf}$ of 0.36 .

\section{EXPERIMENTAL RESULTS}

As a result of studies, it is shown that ozone-air mixture has inhibitory effect on the spores of the studied microscopic fungi. The research lasted within 6 months (November 2018-May 2019) has shown that ozone inhibits fungus growth during storage. The percentage of contamination with Aspergillus flavus after ozone treatment at wheat storage for 6 months without additional contamination with Penicillium nordicum averaged $25 \%$ (75\% was inhibited).

The percentage of residual contamination with Aspergillus flavus at additional contamination with Penicillium nordicum was $40 \%$ (60\% was inhibited). At contamination with Penicillium nordicum, the percentage of residual fungal contamination in both cases was $40 \%$ (60\% was inhibited). Variability of data on the quantitative content of micromycetes at different periods of storage is associated with temperature fluctuations and uneven contamination distribution over the stored grain volume. Changes in the level of fungal contamination with Aspergillus flavus are shown in Figs. 4, 5.

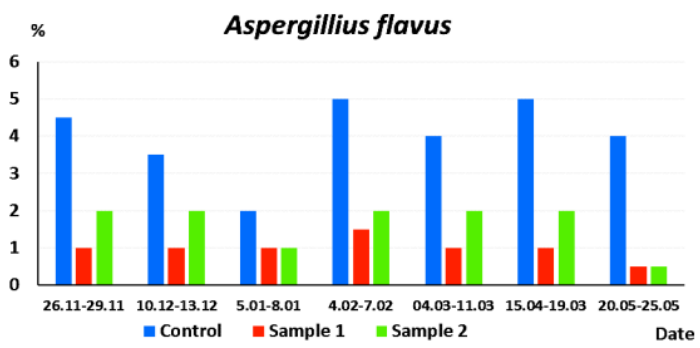

Fig. 4. Dynamics of the influence of ozone-air mixture on Aspergillus flavus contamination for 6 months (in \%) 


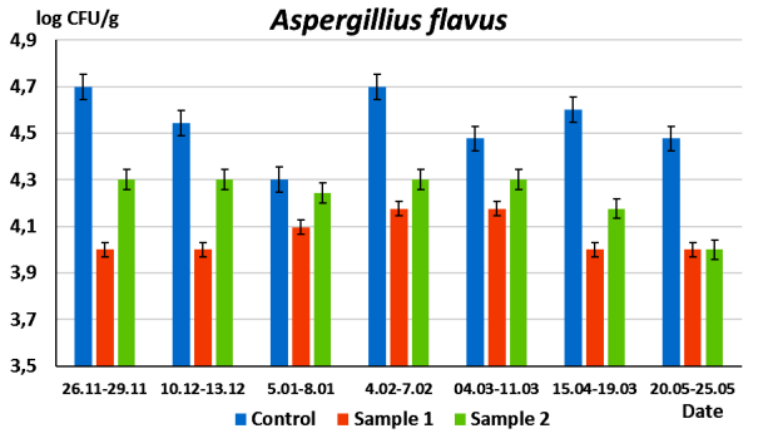

Fig. 5. Dynamics of the influence of ozone-air mixture on Aspergillus flavus contamination for 6 months (in $C F U / g$ )

The Ozone effect on the development of Aspergillus flavus in artificially contaminated maize, as well as of Penicillium verrucosum in artificially contaminated wheat (grain samples were taken 2 times a month) was studied during the experiments. It has been found that ozone not only inhibits fungal growth and its content in samples, but also reduces significantly $d$ the number of colonies in $1 \mathrm{~g}$ of grain (from 3 to 6 times in different grain samples) (Figs. 6, 7).

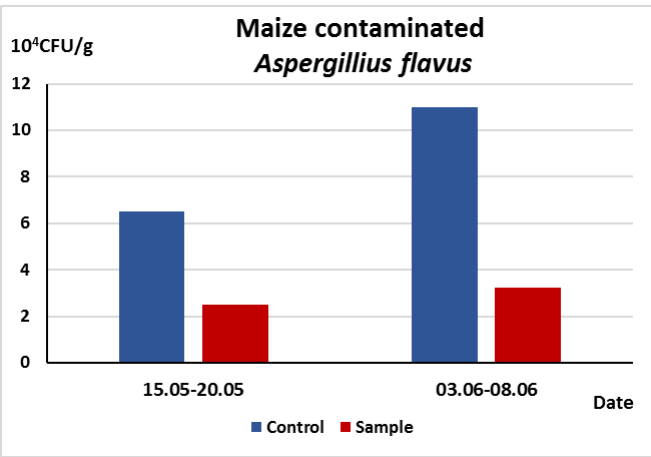

Fig. 6. The influence of ozone-air mixture on Aspergillus flavus in maize grain

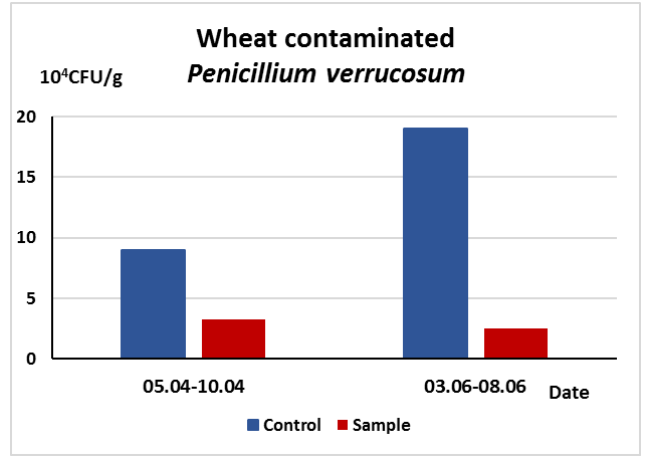

Fig. 7. The influence of ozone-air mixture on Penicillium verrucosum in wheat grain

The effect of ozone on the content of mycotoxins in wheat and maize samples was studied. As a result of the experiments, it was shown that at a low level of wheat grain fungal contamination with Penicillium verrucosum (less than $1 \cdot 10^{4}$ spores/g), Aflatoxins (B1, B2, G1, G2) were not detected in both control and treated samples (less than $0.002 \mathrm{mg} / \mathrm{kg}$ ). Then, the content of Aflatoxins at a high level of fungal contamination (about $30 \cdot 10^{4}$ spores/g) was studied. The culture of Aspergillus flavus was grown on sterile maize grain at the humidity of $70 \%$ and temperature of $27{ }^{\circ} \mathrm{C}$ for 14 days in thermostat.

Maize grain contaminated with Aspergillus flavus is shown in Fig. 8 after the treatment with ozone-air mixture.

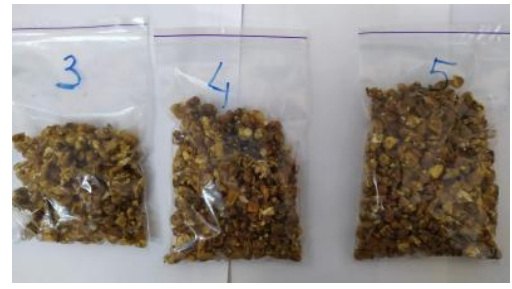

Fig. 8. Maize grain contaminated with Aspergillus flavus and treated by ozone during 3, 4, and 5 days

In Fig. 9, the "Sorbfil" plate is shown in the process of chromatographic run.

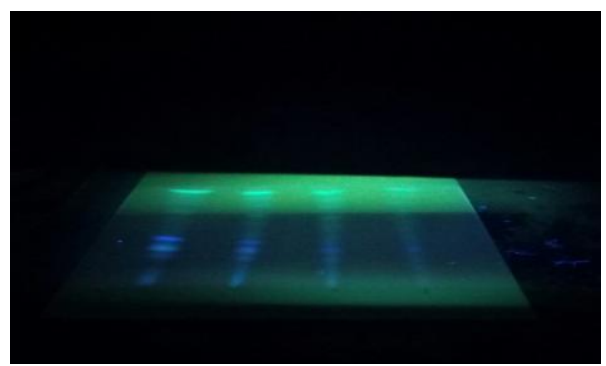

Fig. 9. The plate with Aflatoxin stains in the process of chromatographic run

Changing Aflatoxin B content (in $\mathrm{mg} / \mathrm{kg}$ ) in the reference sample as well as in samples treated with ozone-air mixture for 3, 4, and 5 days is presented in the graph (Fig. 10).

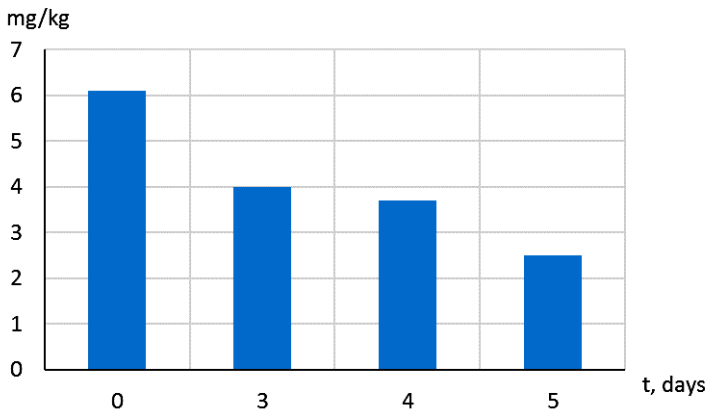

Fig. 10. Changes in the content of Aflatoxin B for the control sample and after the treatment with ozoneair mixture

In the graphs above, it is shown that ozone reduces the content of Aflatoxin B in maize grain by more than 2 times in 5 days of treatment.

\section{CONCLUSIONS}

As a result of studies carried out using a $1000 \mathrm{~kg}$ grain silo, a persistent effect of growth inhibition for Aspergillus flavus up to $75 \%$ and Penicillium nordicum up to $60 \%$ was shown during 6 months. Additional contamination of the part of grain volume with Penicillium nordicum reduced the level of contamination inhibition for Aspergillus flavus to $60 \%$. 
The ozone effect on the development of micromycetes in maize and wheat grain artificially contaminated with Aspergillus flavus and Penicillium verrucosum respectively in $100 \mathrm{~kg}$ silo was studied. It was found that ozone inhibited the growth of fungal contamination and the number of colonies in $1 \mathrm{~g}$ of feed grains decreased on average by 3-6 times.

In accordance with the experimental results on the effect of ozone on the content of mycotoxins in wheat grain contaminated with Penicillium verrucosum at a low level of contamination (less than $1.0 \cdot 10^{4}$ spores/g), Aflatoxins (B1, B2, G1, G2) were not detected (less than $0.002 \mathrm{mg} / \mathrm{kg}$ ). At a high level of maize grain contamination with Aspergillus flavus (more than $3.0 \cdot 10^{5} \mathrm{spores} / \mathrm{g}$ ), the content of Aflatoxins decreased by 2.5 times (by 60\%). These data are consistent with the results of changes in the number of spores after the treatment with ozone-air mixture.

Thus, the efficiency of ozone technologies for largescale storage of grain was shown both to reduce the level of fungal contamination and control the content of mycotoxins in food grains.

\section{ACKNOWLEDGEMENTS}

This work has been carried out within the framework of the MycoKey project of the European Horizon 2020 program.

\section{REFERENCES}

1. L.S. Polak, A.A. Ovsyannikov, D.I. Slovetskiy. Theoretical and applied plasma chemistry. M.: «Nauka», 1975, 304 p.

2. O.V. Manuilenko, A.Yu. Dulphan, V.I. Golota, D.V. Kudin. Ozone decay in chemical reactor with the developed inner surface: air-ethylene mixture // Problems of Atomic Science and Technology. Series
«Plasma Electronics and New Methods of Acceleration» (116). 2018, № 4, p.139-143.

3. V.I. Golota, O.V. Manuilenko, G.V. Taran, L.M. Zavada, D.V. Kudin Decomposition of ethylene in low temperature plasma of barrier less discharge // Problems of Atomic Science and Technology. Series «Plasma Electronics and New Methods of Acceleration» (116). 2018, № 4, p.160-163.

4. Mc Taggart F. Plasma-chemical reactions in electrical discharges. M.: «Atomizdat», 1972, 256 p.

5. V.I. Golota, G.V. Taran, A.A. Zamuriev, P.O. Opalev, S.G. Pugach, S.N. Mankovskyi, V.P. Petrenkova, I.N. Nyska. The use of ozone technologies in grain storage // Problems of Atomic Science and Technology. Series «Plasma Electronics and New Methods of Acceleration» (116). 2018, № 4, p. 185-188.

6. A.M. Kholdoenko. Epizootological monitoring under the conditions of industrial poultry farming // Extended abstract of Cand. Sci. (Veterinary Science) Dissertation. 2002, v. 24, p. 123.

7. V.I. Bilay, N.M. Pidoplichko. Toxin-forming microscopic fungi and the diseases they cause in humans and animals. K.: «Naukova Dumka», 1970, $291 \mathrm{p}$.

8. D. Sutton. Determinant of pathogenic and opportunistic fungi: Translation from English. [Text] / Manual for universities / O. Sutton, A. Fothergill, M. Rinaldi; under general editorship of D.G. Zvyagintsev. M.: «Mir», 2001, 487 p.

9. S.V. Abraskova, Yu.K. Shashko, M.N. Shashko. Biological safety of feed. Minsk: «Belaruskaya Navuka», 2013, 257 p.

Article received 10.09.2020

\section{ПЛАЗМОХИМИЧЕСКИЙ МЕТОД КОНТРОЛЯ КОНТАМИНАЦИИ ГРИБНОЙ ИНФЕКЦИЕЙ ЗЕРНОВЫХ КУЛЬТУР}

\section{Г.В. Таран, С.Г. Пугач, А.А. Замуриев, П.О. Опалев, М.О. Ярошенко}

Приведены результаты экспериментальных исследований влияния обработки озоновоздушной смесью зерновых культур на степень их контаминации микромицетами при искусственном заражении. Исследована динамика степени контаминации зерна пшеницы массой 1000 кг, которое было заражено грибной инфекцией Penicillium nordicum и Aspergillus flavus и хранилось в прототипе промышленной установки для хранения зерна в среде озона в течение 6 месяцев. Приведено исследование влияния озона на угнетение роста микромицетов Aspergillus flavus на зерне кукурузы и Penicillium verrucosum на зерне пшеницы в модельном силосе объемом 100 дм³ $^{3}$ Проведено исследование влияния озона на содержание афлотоксинов в зерне кукурузы, дополнительно зараженном Aspergillus flavus. Показана эффективность озоновых технологий для хранения промышленных партий зерна как для снижения контаминации грибковой инфекции, так и для контроля содержания микотоксинов в продовольственном зерне.

\section{ПЛАЗМОХІМІЧНИЙ МЕТОД КОНТРОЛЮ КОНТАМІНАЦЇ̈ ГРИБНОЮ ІНФЕКЦЕЮ ЗЕРНОВИХ КУЛЬТУР}

\section{Г.В. Таран, С.Г. Пугач, О.О. Замурієв, П.О. Опалєв, М.О. Яроченко}

Наведено експериментальні результати з впливу обробки зерна озоноповітряною сумішшю на рівень штучного зараження зерна мікроміцетами. Наведено динаміку забруднення 1000 кг зерна пшениці, зараженого Penicillium nordicum і Aspergillus flavus, яке зберігалося в прототипі зерносховища в озоновому середовищі протягом 6 місяців. Представлено дослідження впливу озону на пригнічення росту Aspergillus flavus для зерна кукурудзи і Penicillium verrucosum для зерна пшениці в силосі об'ємом 100 дм $^{3}$ Вивчено вплив озону на утримання афлатоксинів у зерні кукурудзи, додатково зараженого Aspergillus flavus. Показана ефективність озонових технологій для великомасштабного зберігання зерна, а також для зниження грибкового зараження і контролю вмісту мікотоксинів у продовольчому зерні. 